\title{
Comparing ATP values with bacterial contamination in a nursing home
}

\author{
IT Overdevest ${ }^{1,2,3^{*}}$, I Willemsen ${ }^{2}$, YJ Hendriks ${ }^{2,4}$, CJ Verhulst ${ }^{2}$, JA Kluytmans ${ }^{2,3,5}$ \\ From 3rd International Conference on Prevention and Infection Control (ICPIC 2015) \\ Geneva, Switzerland. 16-19 June 2015
}

\section{Introduction}

Bacterial surface contamination is an important reservoir for micro-organisms and a potential route for transmission. ATP bioluminescence is a relatively new method to assess environmental contamination, and gives direct results.

\section{Objectives}

We compared ATP bioluminescence with aerobic colony count and presence of ESBL-producing Enterobacteriaceae.

\section{Methods}

The study was performed in a nursing home in the Netherlands during an outbreak of ESBL-producing Enterobacteriaceae, mainly Escherichia coli. During 5 consecutive surveys, ATP measurements (3M, Zoeterwoude, The Netherlands) were performed on several predefined surfaces. ATP measurements were combined with aerobic colony count, using Rodac agar plates in 2 surveys, and selective culture for ESBL-producing Enterobacteriaceae in 3 surveys. ATP bioluminescence was expressed in relative light units (RLU), AAC was expressed in $\mathrm{cfu} / \mathrm{cm}^{2}$; for the analysis a Natural Logarithmic transformation was performed to obtain an normal distribution of the values (LnRLU and LnCFU).

\section{Results}

In total we performed 483 ATP-measurements, 197 ACC cultures and 285 ESBL-selective cultures. Toilet seats were significantly associated with higher RLU $(P<0.001)$, higher prevalence of more than $40 \mathrm{cfu} / \mathrm{cm}^{2}$ on aerobic colony count, but not with difference in prevalence of ESBL-producing Enterobacteriaceae $(P=0.31)$, compared to water taps, kitchen- and living room areas.

'Laboratory for Medical Microbiology, Stichting PAMM, Veldhoven, Netherlands

Full list of author information is available at the end of the article
The ATP and ACC results of the 98 paired samples showed a good correlation between LnRLU and LnCFU $\left(\mathrm{R}^{2}=0.277 ; P<0.001\right)$. Furthermore, LnRLU of the sample sites which yielded an ESBL-producing Enterobacteriaceae was significantly higher than of other the sites $(P=0.016)$.

\section{Conclusion}

Our study showed that ATP bioluminescence has a good correlation with bacterial contamination determined of surfaces. Furthermore, we did find a significant correlation between LnRLU and surface contamination with ESBL-producing Enterobacteriaceae. In conclusion, ATP bioluminescence is a valid replacement for measuring the bacterial contamination of surfaces, and can be a useful tool for direct feedback to assess cleaning properties.

\section{Disclosure of interest}

I. Overdevest: None declared, I. Willemsen: None declared, Y. Hendriks: None declared, C. Verhulst: None declared, J. Kluytmans Consultant for: Pfizer, biomerieux, 3M.

\section{Authors' details \\ ${ }^{1}$ Laboratory for Medical Microbiology, Stichting PAMM, Veldhoven, Netherlands. ${ }^{2}$ Laboratory for Microbiology and Infection Control, Amphia hospital, Breda, Netherlands. ${ }^{3}$ Laboratory for Medical Microbiology and Immunology, St. Elisabeth Hospital, Tilburg, Netherlands. ${ }^{4}$ Thebe Long term care facilities, Breda, Netherlands. ${ }^{5}$ Julius Center for Health Science and Primary Care, University medical Center, Utrecht, Netherlands.}

Published: 16 June 2015

doi:10.1186/2047-2994-4-S1-P28

Cite this article as: Overdevest et al.: Comparing ATP values with bacterial contamination in a nursing home. Antimicrobial Resistance and Infection Control 2015 4(Suppl 1):P28.
C Biomed Central

(c) 2015 Overdevest et al; licensee BioMed Central Ltd. This is an Open Access article distributed under the terms of the Creative Commons Attribution License (http://creativecommons.org/licenses/by/4.0), which permits unrestricted use, distribution, and reproduction in any medium, provided the original work is properly cited. The Creative Commons Public Domain Dedication waiver (http://creativecommons.org/publicdomain/zero/1.0/) applies to the data made available in this article, unless otherwise stated. 